\title{
Case report \\ Maxillary sinus fungus ball: a case report
}

\author{
Dilara Nil Tomrukçu, ${ }^{1}$ Taha Emre Köse (iD,${ }^{1 *}$ \\ Engin Dursun ${ }^{2}$ \\ ${ }^{1}$ Department of Oral and Maxillofacial Radiology, Faculty \\ of Dentistry, ${ }^{2}$ Department of Otolaryngology, Faculty of \\ Medicine, Recep Tayyip Erdoğan University, Rize, Turkey
}

\begin{abstract}
INTRODUCTION: Sinus fungus ball is a non-invasive sinus disease and the incidence of this disease has increased in recent years. The aim of this case report was to present the radiographic and clinical findings of a patient who was diagnosed with a sinus fungus ball.

CASE RePort: A 40-years-old female patient referred to Recep Tayyip Erdoğan University Faculty of Dentistry, Oral and Maxillofacial Radiology Department with the complaint of pain in the head and orofacial region. Any dental reason that may cause the pain was not detected, however, a foreign body at the left maxillary sinus was seen on a panoramic radiograph taken from the patient. Then, cone-beam computed tomography images were obtained. These images revealed total opacification of the left maxillary sinus with calcified areas. Due to the complaint of the patient and clinical and radiographic findings, magnetic resonance images were obtained with the initial diagnosis of possible fungal sinusitis. Magnetic resonance images supported this diagnosis. Upon this, the patient was operated and histopathological examination was made. The presence of fungus compatible with the Aspergillus type was confirmed with histopathologic examination.
\end{abstract}

Conclusion: Dentists must be aware of maxillary sinus fungal infections in patients with facial pain.

KEYWORDS: Cone-beam computed tomography; maxillary sinus; mycoses

Citation: Tomrukçu DN, Köse TE, Dursun E. Maxillary sinus fungus ball: a case report. Acta Odontol Turc 2020;37(2):54-7

EDIToR: Zühre Zafersoy Akarslan, Gazi University, Ankara, Turkey

Copyright: @ 2020 Tomrukçu et al. This work is licensed

Received: September 18, 2019; Accepted: December 10, 2019 ${ }^{*}$ Corresponding author: Dr. Taha Emre Köse, Department of Oral and Maxillofacial Radiology, Faculty of Dentistry, Recep Tayyip Erdoğan University, Menderes Avenue, no: 64, 53100, Rize, Turkey

E-mail: tahaemre@gmail.com under a Creative Commons Attribution License. Unrestricted use, distribution and reproduction in any medium is permitted provided the original author and source are credited.

FundING: None declared.

CONFLICT OF INTEREST: The authors declare no conflict of interest related to this study.

\section{INTRODUCTION}

Paranasal sinus diseases consist the whole sinus pathologies with a wide range of diseases from inflammatory lesions to neoplasms. ${ }^{1,2}$ In recent years with the increased incidence of long antibacterial treatments high dose long term steroid treatments, radiotherapy treatment at dentomaxillofacial area and diseases or treatments that cause immunodeficiency the incidence of the fungal sinusitis have increased. However, in rare cases fungal sinusitis may be seen in immunologically healthy patients. ${ }^{3}$

Fungal sinusitis constitutes $12 \%$ of the chronic sinusitis patients and $13-28 \%$ of the isolated maxillary sinus infections. ${ }^{4}$ The first possible report for the fungal sinusitis may be Plaignoud's case that reported a fungal tumor at a 22-year-old soldier with maxillary pain treated with cautery. ${ }^{5}$

There are 2 types of fungal sinusitis based on the penetration capability as invasive and non-invasive. Acute fulminant and chronic silent are the 2 subtypes of invasive fungal sinusitis. Histopathologically invasive sinusitis shows invasion to the sinus mucosa and tissue necrosis. Non-invasive type which is more benign than the invasive types is divided into 2 subtypes as mycetoma and allergic fungus ball. In addition, some researchers claim that the term 'rhinosinusitis' is more appropriate as many sinus diseases affect not only the paranasal sinuses but also the nasal cavity. ${ }^{6}$

Sinus fungus ball (SFB) is a fungal rhinositis type also called as aspergilloma or mycetoma. It originates from aspergillus types. In this type, fungal hyphae elements do not show invasion to the mucosa, they are rather inside the sinus. ${ }^{7}$

The aim of this case report is to present a patient with SFB who has facial pain that may be confused with dental pain. 


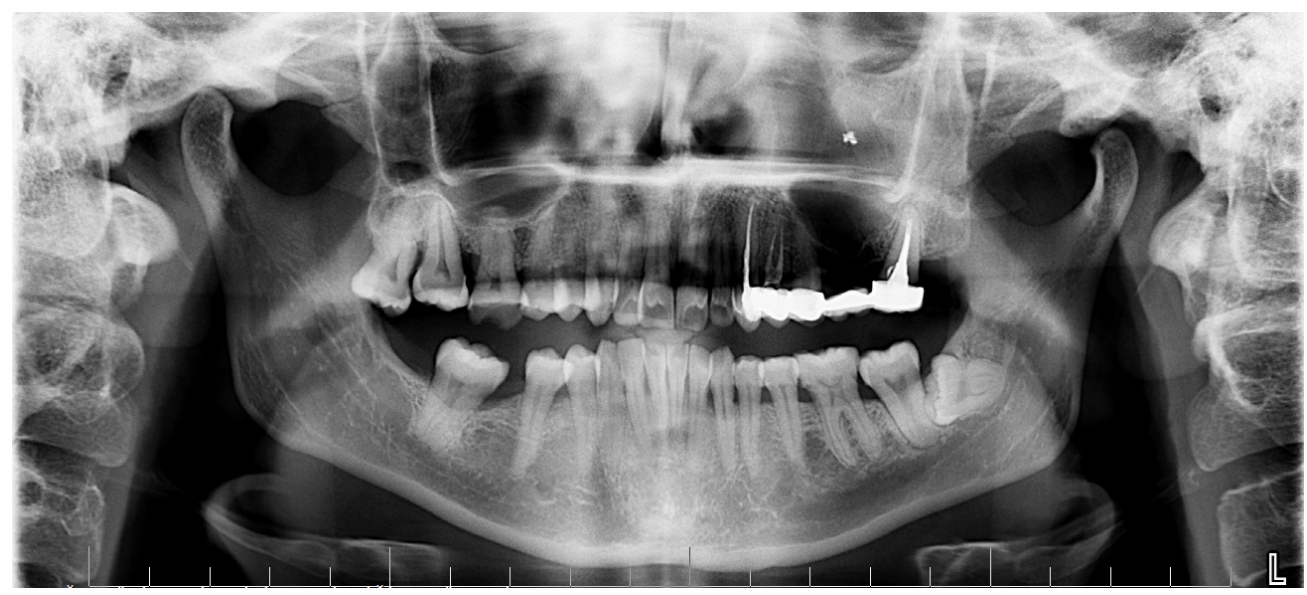

Figure 1. Patient's panoramic radiography shows a dense foreign body in the left maxillary sinus

\section{Case Report}

A 40-year-old female patient referred to the Recep Tayyip Erdoğan University, Faculty of Dentistry, Oral and Maxillofacial Radiology Department due to head and orofacial pain that concentrated on the left maxillary area. Patient also complained of post-nasal drip and pressure sensation on the left cheek area. Patient was systemically healthy with no history of antimicro$\mathrm{bial} / \mathrm{steroid}$ or any other therapy that may cause immunodeficiency.

Panoramic radiography (Planmeca ProMax 3D Classic, Planmeca Oy; Helsinki, Finland) revealed a metallic density object located in the left maxillary sinus (Figure 1). A cone-beam computed tomography (CBCT) (Planmeca ProMax 3D Classic, Planmeca Oy; Helsinki, Finland) scan was obtained to assess the left maxillary sinus and left molar area. In CBCT images, left maxillary sinus seemed almost totally opacified with soft tissue density material and indistinct calcifications, in addition to sclerosis of the maxillary sinus walls (Fig-

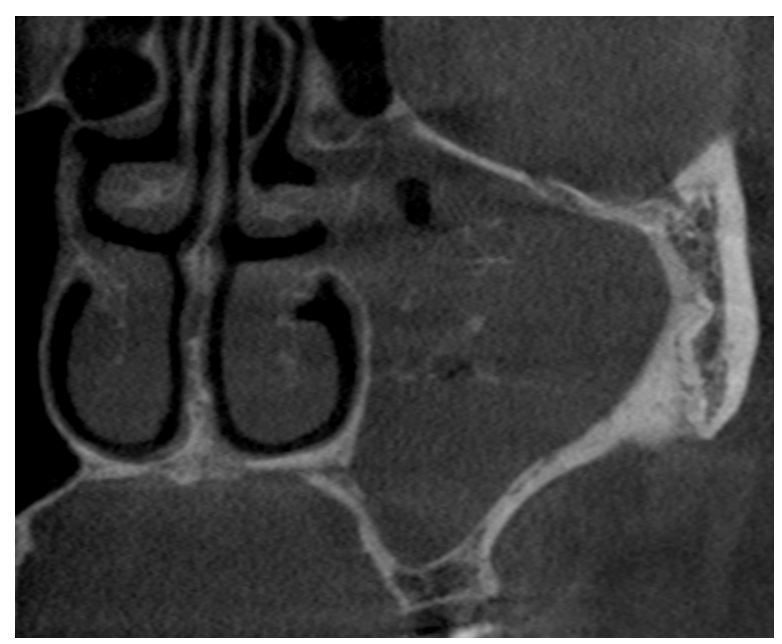

Figure 2. CBCT image shows nearly total opacification of the maxillary sinus with indistinct calcified areas and sclerosis of the sinus bony wall ure 2). Magnetic resonance imaging (MRI) T1 weighted scan of the patient revealed a mass inside the maxillary sinus isointense to muscle. In T2 weighted images, the mucosal thickening areas seemed as a hyperintense and hypointense mass regarded as fungus ball located in the middle of the sinus (Figure 3).

The initial diagnosis was made as fungal rhinosinusitis and the patient was referred to the otorhinolaryngology clinic. The patient was operated and, in excisional biopsy periodic acid-schiff (PAS) + fungal hype, active chronic inflammatory areas were seen (Figure 3 ). In histopathologic sections, typical morphologic findings regarding to Aspergillus types were present.

\section{Discussion}

DeShazo et al. ${ }^{8}$ repored clinical, radiological and histopathological criteria for the diagnosis of a fungal ball. These criteria are as following: sinus opacification (in the form of agglomeration or not), mucopurulent cheese or clay-like material, fungal hyphae cluster adjacent to the sinus mucosa, chronic inflammation of the intestinal mucosa (lymphocytes, plasma cells, mast cells and eosinophils may be found, but there is no allergic mucin and granulomas), blood vessels and bone tissue without fungal invasion. ${ }^{8}$

Lungs are acknowledged as the most affected area, yet in recent years published paranasal mycetoma cases seemed to increase. ${ }^{9}$ It is suggested that development of a fungus ball in the maxillary sinus may be as a result of zinc oxide usage in dental operations..$^{10}$ In our patient root canal treatment was present in left first premolar and second molar teeth.

SFB is detected unilaterally at $94 \%$ of the patients and mostly seen in sphenoid sinuses. ${ }^{9}$ This disease is generally seen in middle aged women with a normal immune system. ${ }^{11}$ Our patient was a middle aged healthy woman with no known diseases.

Clinical symptoms of the SFB may mimic chronic sinusitis that may include facial/head pain, nasal obstruc- 


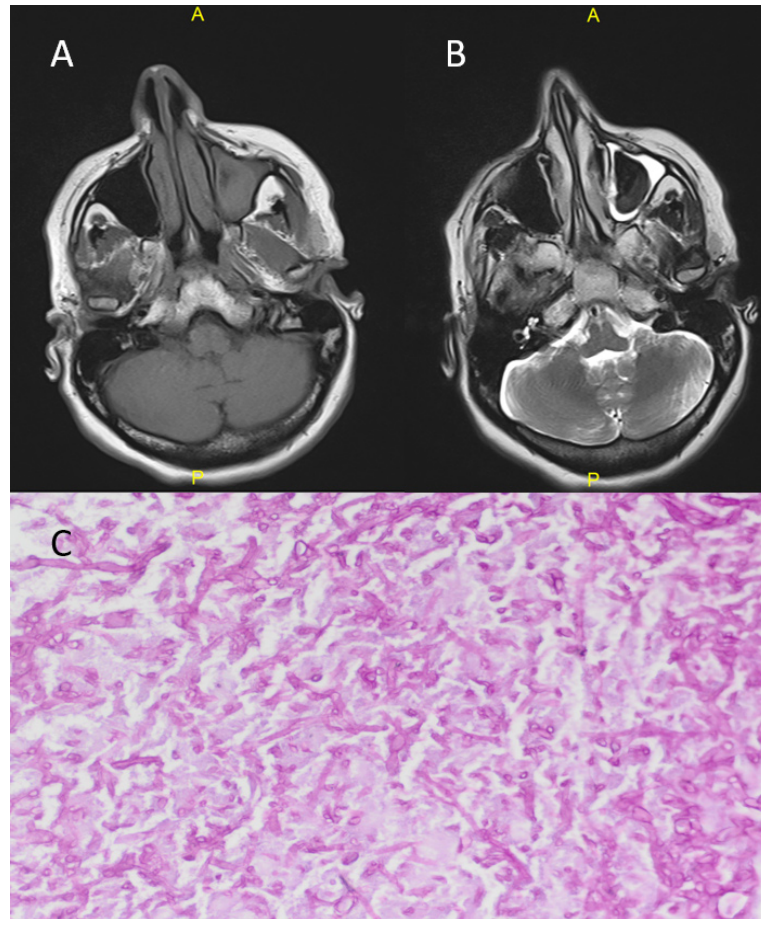

Figure 3. Magnetic resonance and histopathologic images; (A) T1 weighted image shows maxillary sinus filled with mass isointense to the muscle, (B) T2 weighted image shows hypointense maxillary fungus ball, (C) Histopathological image shows PAS + septation and fungal hyphae image with branching.

tion, chronic cough and nasal discharge. Also, sphenoid sinus fungus balls may cause visual disorders like unilateral vision loss, blurred vision and diplopia. ${ }^{12}$ Our patient had maxillary pain at the left side of her head and face for 2 years as well as nasal obstruction and nasal discharge.

In computed tomography (CT) images, SFB is usually presented unilaterally. Almost total opacification of the sinus is present and half of the cases have hyperdense areas mimicking foreign bodies. ${ }^{13}$ These hyperdense areas are the result of metabolic calcium deposits in fungal hyphae. This radiographic image is highly specific for the diagnosis of the disease. ${ }^{14}$ Also sclerosis at sinus bony walls, mucosal thickening and bony erosion due to pressure of the mass may be seen. ${ }^{9}$ In our patient, foreign body with metallic density which was considered as a root canal sealer and nearly total opacification of the left maxillary sinus was seen.

In MRI, fungus ball is seen as hypointese or isointense areas due to absence of free water at the T1 weighted sequences. In the T2 weighted sequences fungus ball is seen as a hypointense mass. Inflamed sinus mucosa may be seen as thickened and hyperintense in the T2 sequences. Especially on the T2 weighted sequences, the image of fungus ball may be confused with air due to macromolecular protein bindings. ${ }^{15,16}$ In our patient, the fungus ball was seen in the $\mathrm{T} 1$ weighted sequences as isointense with muscle. In the T2 weighted sequences, the inflamed mucosa was seen as hyperintense and fungus ball was seen as a hypodense area.

The treatment of the fungus ball is surgical removal of the mass. Prognosis is well and recurrence is rare..$^{15}$ In our case, the mass was removed surgically and the patient was called for follow up for possible recurrence.

\section{CONCLUSION}

In patients with pain in maxillary sinus area and maxillary molar teeth region, SFB must be in mind for a possible cause.

\section{REFERENCES}

1. Parsons $\mathrm{C}$, Hodson N. Computed tomography of paranasal sinus tumors. Radiology 1979;132:641-5.

2. Fagnan LJ. Acute sinusitis: A cost effective approach to diagnosis and treatment. Am Fam Physician 1998;58:1795-802,805-6.

3. Blitzer A, Lawson W. Fungal infections of the nose and paranasal sinuses. Part I. Otolaryngol Clin North Am 1993;26:1007-35

4. Granville L, Chirala M, Cernoch P, Ostrowski, M, Truong LD. Fungal sinusitis: histologic spectrum and correlation with culture. Hum Pathol 2004;35:474-81

5. Chakrabarti A, Das A, Panda NK. Overview of fungal rhinosinusitis. Indian J Otolaryngol Head Neck Surg 2004;56:251-8.

6. Ferguson BJ. Definitions of fungal rhinosinusitis. Otolaryngol Clin North Am 2000;33:227-35.

7. Chakrabarti A, Denning DW, Ferguson BJ, Ponikau J, Buzina W, Kita $\mathrm{H}$, et al. Fungal rhinosinusitis: a categorization and definitional schema addressing current controversies. Laryngoscope 2009;119:1809-18.

8. deShazo RD, O'Brien M, Chapin K, Soto-Aguilar M, Swain R, Lyons $\mathrm{M}$, et al. Criteria for the diagnosis of sinus mycetoma. J Allergy Clin Immunol 1997;99:475-85.

9. Klossek JM, Serrano E, Péloquin L, Percodani J, Fontanel JP Pessey JJ. Functional endoscopic sinus surgery and 109 mycetomas of paranasal sinuses. Laryngoscope 1997;107:112-7.

10. Mensi M, Salgarello S, Pinsi G, Piccioni M. Mycetoma of the maxillary sinus: endodontic and microbiological correlations. Oral Surg Oral Med Oral Pathol Oral Radiol Endod 2004;98:119-23.

11. Pagella F, Matti E, De Bernardi F, Semino L, Cavanna C, Marone $P$, et al. Paranasal sinus fungus ball: diagnosis and management. Mycoses 2007;50:451-6.

12. Grosjean $P$, Weber R. Fungus balls of the paranasal sinuses: a review. Eur Arch Otorhinolaryngol 2007;264:461-70.

13. Stammberger $H$, Jakse $R$, Beaufort $F$. Aspergillosis of the paranasal sinuses: $x$-ray diagnosis, histopathology, and clinical aspects. Ann Otol Rhinol Laryngol 1984;93:251-6.

14. Chen JC, Ho CY. The significance of computed tomographic findings in the diagnosis of fungus ball in the paranasal sinuses. Am J Rhinol Allergy 2012;26:117-9.

15. Aribandi M, McCoy VA, Bazan C 3rd. Imaging features of invasive and noninvasive fungal sinusitis: a review. Radiographics 2007;27:1283-96.

16. Koenig LJ, Tamimi D, Petrikowski CG, Harnsberger HR, Ruprecht A, Benson BW. Diagnostic imaging: oral and maxillofacial. 2nd ed. Altona, Manitoba: Amirsys Publishing; 2017 


\section{Maksiller sinüs yerleşimli mantar topu: olgu bildirimi}

\section{ÖZet}

TANITIM: SinüS mantar topu benign non-invaziv sinüs hastalığıdır ve bu hastalığın görülme sıklığı son yıllarda artmıştır. Bu olgu sunumunun amacı sinüs mantar topu tanısı konulan bir hastanın klinik ve radyolojik bulgularını sunmaktır.

OLGu BiLdiRimi: Kırk yaşında kadın hasta, baş ve orofasiyal bölgede ağrı şikayetiyle Recep Tayyip Erdoğan Üniversitesi Diş Hekimliği Fakültesi Oral ve Maksillofasiyal Radyoloji Anabilim dalına başvurdu. Hastadan alınan panoramik radyografide dental ağrıya neden olabilecek herhangi bir etken gözlenmemekle birlikte, sol maksiller sinüste yabancı cisim saptandı. Bunun üzerine hastadan konik ışınlı bilgisayarlı tomografi görüntüleri elde edildi. $\mathrm{Bu}$ görüntülerde sol maksiller sinüste kalsifiye bölgeler içeren total opasifikasyon saptandı. Hastanın şikayeti ile yapılan klinik ve radyografik muayene sonucunda fungal sinüzit ön tanısı ile hastadan manyetik rezonans görüntüleme (MRG) istendi. MRG görüntüleri bu tanıyı destekledi. Bunun üzerine hasta opere edilerek histopatolojik inceleme yapıldı. Histopatolojik incelemede Aspergillus tipinde fungus ile uyumlu olduğu doğrulandı.

Sonuç: Diş hekimleri fasiyal ağrısı olan hastalarda fungal enfeksiyonların etken olabileceğinin farkında olmalıdır.

Anahtar Kelimeler: Konik ışınlı bilgisayarlı tomografi; maksiller sinüs; mantar hastalıkları 